\title{
Inovasi Aplikasi Media Pembelajaran Tari Bali Berbasis Android
}

\author{
Ni Made Dian Widiastuti \\ Pendidikan Seni Budaya, Pascasarjana Universitas Negeri Surabaya, Gedung K9 Kampus UNESA \\ Ketintang, Surabaya, 60231, Indonesia \\ dianwidiastuti19@ymail.com
}

Tari Bali sebagai seni yang cukup populer di masyarakat dengan jumlah peminat untuk mempelajarinya terus bertambah. Bertambahnya peminat tidak diimbangi dengan jumlah media yang ada untuk membantu proses pembelajarannya, mengingat bahwa belajar tari Bali tidak mudah dengan tingkat kesulitan yang berbeda-beda pada setiap tariannya dan waktu yang diperlukan tidak sedikit. Bagi masyarakat modern yang dinamis tidak semua orang memiliki waktu khusus untuk belajar tari di sanggar, sehingga diperlukan teknologi atau media pembelajaran yang praktis sebagai alternatif dalam belajar tari Bali. Penelitian ini bertujuan untuk mendeskripsikan (1) spesifikasi produk aplikasi media pembelajaran tari Bali berbasis android, (2) proses pengembangan media pembelajaran tari Bali berbasis android dengan mengambil materi tari Cendrawasih. Penelitian ini menggunakan metode penelitian dan pengembangan atau Research and Development (R\&D) dengan model pengembangan yang digunakan sebagai acuan yaitu model Four-D oleh Thiagarajan (1974). Teknik pengumpulan data yang digunakan dalam proses penelitian ini adalah dengan observasi dan wawancara. Hasil penelitian menunjukan bahwa (1) produk yang dikembangkan berupa aplikasi pembelajaran tari Cendrawasih yang disajikan kedalam smartphone berbasis android dengan sajian materi secara bertahap mulai dari deskripsi, ragam gerak tari, hingga kuis (2) proses pengembangannya yang telah dilakukan saat ini menggunakan tahapan define, design, develop. Kegiatan define dengan menentukan masalah yang terjadi, design merancang materi ataupun tampilan media, dan develop adalah mewujudkan hasil rancangan kedalam bentuk nyata.

Kata kunci: inovasi, media, tari bali, android

\section{Innovation Of Learning Media Application Of Balinese Dance Based On Android}

Balinese Dance is popular art in the community with the number of enthusiasts to learn it continues to grow. Increased interest is not matched by the amount of media available to aid the learning process, considering that learning Balinese dance is not easy with different difficulty levels in each dance and the time required is not small. For the dynamic modern society not everyone has a special time to learn dance in the studio, so it takes technology or practical learning media as an alternative in learning Balinese dance. This study aims to describe (1) the specification of application of Balinese dance-based dance learning media, (2) the process of developing Balinese dance based learning media by taking Cendrawasih dance material. This research uses research and development method or Research and Development (R \& D) with the development model used as a reference that is Four-D model by Thiagarajan (1974). Data collection techniques used in this research process is by observation and interview. The result of research shows that (1) the product developed in the form of Cendrawasih dance learning application which is presented into android based smartphone with gradual material presentation starting from description, dance variety, to quiz (2) development process which has been done now using define stage, design, develop. Activities define by determining the problem that occurs, design material or media display, and develop is to realize the results of the design into the real form.

Keywords: innovation, media, balinese dance, android

Proses Review : 1 - 31 Maret 2018, Dinyatakan Lolos: 9 Mei 2018 


\section{PENDAHULUAN}

Tari Bali sebagai salah satu dari sekian banyak warisan budaya seni yang masih lestari di Indonesia. Kecantikan dalam tari Bali tampak pada gerakan-gerakannya yang bersifat ekspresif melalui wajah/mimik muka disertai penonjolan gerakan mata yang sangat tegas namun menarik. Setiap gerakannya mengikuti ritme musik pengiring baik dengan tempo cepat ataupun lambat, sehingga tari Bali juga dikenal dengan sifatnya yang enerjik dan dinamis. Tidak hanya dari karakteristik gerakannya, tari Bali juga menarik apabila dilihat dari bagian tata rias dan kostum. Tata rias wajah yang digunakan dalam tari Bali memiliki pakemnya sendiri, yakni dengan memadukan tiga warna (kuning, merah dan biru) pada kelopak mata.

Karakteristik kostum tari Bali pada umumnya menggunakan motif-motif ukiran Bali dengan sentuhan warna emas pada kain ataupun hiasan yang berbahan dari kulit. Perpaduan warna yang digunakan cenderung meriah dan kontras namun tetap memiliki nilai keindahan pada kostum tari Bali. Melalui keunikan dan kekhasan yang dimiliki, sehingga banyak masyarakat lokal ataupun luar negeri mengagumi dan tertarik untuk menyaksikan pertunjukan tari Bali. Seiring berjalannya waktu, para penikmat seni dan wisatawan dari berbagai kalangan tersebut, tidak hanya sebagai penonton pertunjukan, tetapi ada pula yang tertarik untuk terjun langsung mempelajarinya. Hal itu dapat dilihat dari adanya peserta didik dari luar Bali yang datang khusus belajar praktek tari Bali baik belajar privat maupun bergabung dalam sanggar-sanggar tari, bahkan ada yang menempuh studi di perguruan tinggi seni.

Dalam proses pembelajarannya, tari Bali memiliki tahapan tersendiri untuk membentuk gerak yang dinamis. Strategi mengajar dalam belajar tari Bali beraneka ragam, seperti mengajarkan sikap badan terlebih dahulu, langsung mengajarkan ragam gerak, dan ada pula yang memberikan gerak dasar dengan menggunakan ketukan. Beragamnya strategi yang dapat digunakan, membuktikan bahwa dalam belajar tari Bali tidaklah mudah, yaitu harus mampu membentuk dasar yang baik sebagai pondasi untuk melanjutkan pada materi tari berikutnya. Di zaman yang modern saat ini, masalah dalam belajar tari Bali tidak hanya mengenai dasar yang harus kuat, tetapi waktu yang juga dibutuhkan tidak sedikit. Bagi masyarakat modern yang dinamis tidak semua orang memiliki waktu khusus untuk belajar tari di sanggar, sehingga diperlukan teknologi atau media pembelajaran yang praktis sebagai alternatif dalam belajar tari Bali.

Media pembelajaran sebagai alat bantu berupa fisik maupun nonfisik yang sengaja digunakan sebagai perantara antara guru dan siswa dalam memahami materi pembelajaran agar lebih efektif dan efisien. Media pembelajaran harus mampu menarik dan menuntun siswa untuk memahami isi pembelajaran tersebut. Media sering dikaitkan dan dinilai sebagai teknologi pembelajaran ((Musfiqon, 2012:27). Pada zaman yang serba maju saat ini, teknologi telah berkembang dengan pesat, sehingga tidak dapat dipungkiri adanya perubahan selera, gaya hidup dan pola pikir masyarakatnya. Perubahan tersebut dapat dilihat dari kehidupan masyarakat saat ini dengan lebih menyukai sesuatu yang praktis dan fleksibel (dapat digunakan kapan dan dimanapun). Salah satu teknologi yang sedang populer saat ini adalah audio visual (video) dan android. Video menjadi media yang digemari saat ini, karena mampu menampilkan suara dan gambar bergerak, sedangkan perkembangan android memicu munculnya gadget-gadget pintar (smartphone) yang digemari oleh berbagai kalangan baik orang tua, dewasa, bahkan anak usia dini. Berdasarkan data kutipan dari Lembaga Riset Digital Marketing Emarketer memperkirakan pada tahun 2018 jumlah pengguna aktif smartphone di Indonesia lebih dari 100 juta orang. Dengan jumlah sebesar itu, Indonesia telah menjadi negara dengan pengguna aktif smartphone terbesar keempat di dunia setelah Cina, India, dan Amerika (sumber: https// kominfo. go.id. Kementerian Komunikasi dan Informatika).

Besarnya jumlah pengguna gadget di Indonesia menjadikan smartphone sebagai media yang dapat dimanfaatkan untuk pengetahuan, pengenalan, termasuk pembelajaran tarian Bali. Sejalan dengan pernyataan tersebut untuk membantu agar pembelajaran tari tidak dibatasi waktu dan tempat, maka dikembangkan sebuah inovasi baru berupa video yang dikemas kedalam aplikasi pembelajaran dengan mengambil materi tari Cendrawasih. Tari Cendrawasih merupakan tarian yang menggambarkan kehidupan burung Cendrawasih di hutan Irian Jaya pada musim mengawan atau musim kawin tiba. Gerakan-gerakan dari tarian ini telah dikembangkan kedalam bentuk-bentuk baru sesuai dengan tema tarian ini, sehingga memiliki tingkat kesulitan yang berbeda dari tari lainnya. Dengan tingkat kesulitan yang dimiliki, maka tidak dapat dipungkiri adanya kendala dalam proses pembelajarannya. Kendala tersebut berupa kesulitan dalam menghafalkan ragam gerak tariannya (Observasi di Sanggar Ekanta Swavita Budaya Surabaya, 22 Desember 2017). Penggunaan video pembelajaran ini bermanfaat dalam meningkatkan kompetensi belajar, hal ini diperkuat dengan konsep Vernom (dalam Suwidnya, 2014:70) bahwa melibatkan teknologi audio visual dalam pembelajaran mampu meningkatkan kemampuan belajar sebesar 50\% dari pada tanpa mempergunakan media.

Video pembelajaran tari Cendrawasih berbasis android ini memberikan empat keuntungan kepada penggunanya, yaitu (1) pembelajaran tari diperagakan langsung oleh seorang peraga dan disusun secara sistematis dari bagian sederhana hingga kompleks, sehingga siswa dapat mempelajarinya secara bertahap; (2) pembelajaran dapat dilakukan secara mandiri tanpa dibatasi waktu; (3) jika dipelajari secara bersama, aplikasi ini dapat dihubungkan langsung ke laptop melalui kabel USB dan bantuan aplikasi Vysor, sehingga tampilan video dapat ditampilkan ke laptop. Jadi 
video dapat disaksikan bersama-sama; (4) video pembelajaran melalui android ini memberikan keuntungan bagi penggunanya, selain fleksibel, aplikasi yang diunduh sekali, dapat bertahan dan digunakan lebih lama dibandingkan dengan menggunakan media lainnya.

\section{METODE PENELITIAN}

Jenis penelitian yang digunakan adalah metode penelitian dan pengembangan atau Research and Development (R\&D) yang digunakan untuk menguji efektivitas suatu produk (Sugiyono, 2016:473). Adapun model pengembangan yang digunakan sebagai acuan yaitu model Four-D oleh Thiagarajan (1974). Dalam model ini terdapat tahapan-tahapan yang dapat digunakan sebagai pedoman pelaksanaan, yaitu pendefinisian (define), perancangan (design), pengembangan (develope), dan penyebaran (disseminate). Teknik pengumpulan data dalam penelitian ini adalah observasi dan wawancara.

\section{ANALISIS DAN INTERPRETASI DATA}

\section{Spesifikasi Aplikasi Pembelajaran Tari Bali Berbasis Android}

Spesifikasi produk yang dihasilkan dalam pengembangan ini berupa video pembelajaran berbasis android terkait pembelajaran tari Cendrawasih. Adapun produk yang dirancang memiliki spesifikasi sebagai berikut.

\section{Produk Secara Fisik}

Media pembelajaran secara fisik berupa a) video dalam bentuk aplikasi yang dikembangkan menggunakan program android studio; b) aplikasi ini disajikan ke dalam smartphone bersistem operasi android; c) aplikasi video pembelajaran tari Cendrawasih dapat dijalankan dengan baik pada gadget dengan spesifikasi minimum RAM 3.0 $\mathrm{GB}$, kapasitas penyimpanan $16 \mathrm{~GB}$, dan sistem operasi android; d) desain aplikasi ini sederhana agar mudah dioperasionalkan dengan pengambilan video di Taman Budaya Art Centre Denpasar; e) layout berwarna hijau toska dan abu-abu dengan penambahan audio musik tari Cendrawasih dan musik instrumen; f) jenis huruf Lucida Callygraphy dengan ukuran judul 14 pixel dan jenis huruf pada isi adalah Poor Richard dengan ukuran 12 pixel; g) bahasa yang digunakan bersifat lugas, komunikatif, dan jelas sehingga memudahkan dalam memahami isi materi.

\section{Isi Produk}

Video pembelajaran tari Cendrawasih berbasis android ini berisi tentang deskripsi tari Cendrawasih disertai slide show foto tari Cendrawasih, video bentuk dasar gerak tari meliputi tahap 1 (sikap badan dan kaki), tahap 2 (sikap tangan, kepala, dan mata), dan tahap 3 (sikap pokok dalam tari Cendrawasih), ragam gerak tari Cendrawasih terdiri dari peran jantan dan peran betina yang dikelompokkan menjadi pepeson, pengawak dengan bagian I dan II, pengecet serta pekaad, gerak keseluruhan, komposisi tari, kostum tari, dan kuis. Media tari ini dipandu langsung oleh peneliti dibantu dengan penari peraga putri yang telah memiliki pengalaman dan berkompeten di bidang tari.

\section{Proses Pengembangan Aplikasi Pembelajaran Tari Bali Berbasis Android}

Proses dalam pengembangan aplikasi pembelajaran tari Bali yaitu tari Cendrawasih berbasis android dilakukan dengan menggunakan desain model Four-D dengan empat tahapan yaitu, pendefinisian (define), perancangan (design), pengembangan (develop), dan penyebaran (disseminate). Saat ini tahapan yang telah terlaksana sampai pada langkah develop atau pengembangan. Berikut penjelasan mengenai tahapan tersebut.

\section{Tahap Pendefinisian (Define)}

Pada tahap definisi (define), terdapat lima tahap pokok untuk merumuskan pendefinisian, yaitu analisis ujung depan, analisis siswa, analisis tugas, analisis konsep, dan perumusan tujuan.

\section{Analisis Ujung Depan}

Analisis ini dilakukan untuk menyelesaikan masalah yang dihadapi sehingga perlu dibuat aplikasi pembelajaran tari dengan mengambil materi tari Cendrawasih berbasis android. Berdasarkan hasil dari observasi, masalah yang ditemukan yaitu tidak semua masyarakat saat ini dapat belajar menari di lembaga kursus akibat keterbatasan waktu, jarak, dan ekonomi serta tingkat kesulitan yang dimiliki dalam belajar menari Bali khususnya tari Cendrawasih.

\section{Analisis Siswa}

Pada tahap kedua ini, peneliti mulai menemukan karakteristik siswa melalui observasi awal yang dilakukan. Analisis ini dilakukan agar rancangan pengembangan media video pembelajaran yang disusun dapat efektif membantu siswa dalam pembelajaran tari. Dengan mengetahui karakteristik siswanya terlebih dahulu, maka peneliti dapat mempertimbangkan batas pengembangan media video yang akan dibuat, sehingga dapat diterima oleh siswa sesuai tujuan pembelajaran. Siswa yang mengalami kendala dalam proses belajar tari Cendrawasih adalah siswa yang cenderung belum memiliki kemampuan dasar tari yang matang, sehingga terjadi kesulitan dalam meresapi dan menghafalkan gerak tari. Berdasarkan hal tersebut, maka pembelajaran tari dilakukan dengan memberikan materi secara bertahap, lebih rinci serta konkrit (nyata) agar siswa mampu menghayati kebenaran dari gerak tari.

\section{Analisis Tugas}

Pada tahap ini kegiatan yang dilakukan adalah mulai mengidentifikasi kegiatan yang sesuai dan harus dikerjakan untuk mencapai kompetensi menarikan tari Cendrawasih dengan benar. Jadi kegiatan yang dilakukan adalah (1) memahami bentuk dasar gerak tarinya terlebih dahulu; (2) menghafalkan ragam gerak tari Cendrawasih berdasarkan pembabakan; (3) mempraktekan gerakan tari Cendrawasih berdasarkan pemahaman yang dilakukan sebelumnya. 


\section{Analisis Konsep}

Pada tahap ini hal-hal pokok utama yang akan dipelajari mulai diidentifikasi dan disusun dalam bentuk sistematis

\section{Perumusan Tujuan Pembelajaran}

Setelah siswa mempelajari materi dalam video berbasis android yang dikembangkan maka akan mampu mendeskripsikan dan mempraktekan ragam gerak tari Cendrawasih dengan lebih mudah dan praktis.

\section{Tahap Perancangan (Design)}

Tahap ini dilakukan untuk menyusun suatu media video yang dapat digunakan dalam pembelajaran tari. Adapun tahap perancangan ini meliputi merancang materi dan media. Merancang materi terdiri dari merancang isi pembelajaran yang akan disajikan dan merancang media meliputi perancangan desain aplikasi. Berikut penjelasan mengenai tahap perancangan produk.

\section{Merancang materi}

Dalam proses merancang materi hal yang perlu diperhatikan adalah penyususnan menu materi. Perancangan materi dengan sistematis tentunya dapat mempermudah peserta didik dalam memahami pelajaran, sehingga tujuan pembelajaran dapat tercapai. Materi dalam video berbasis android ini, dikelompokkan menjadi tujuh pokok bahasan utama yaitu deskripsi tari secara lisan, materi bentuk dasar gerak tari terbagi menjadi tahap I, II, dan III, ragam gerak tari Cendrawasih disajikan menjadi gerak peran jantan dan betina, gerak keseluruhan, komposisi tari Cendrawasih, pemakaian kostum dan kuis dalam bentuk obyektif mengenai tari Cendrawasih. Disamping itu materi dalam aplikasi ini juga menyajikan menu "tentang kami" yang berisikan identitas aplikasi.

\section{Merancang Media}

Perancangan media dilakukan untuk menentukan jenis perangkat yang digunakan dalam merancang video berbasis android, baik perangkat keras ataupun perangkat lunak. Media dirancang dengan memanfaatkan perangkat lunak berupa android studio untuk membantu menjalankan sistem pada android. Media yang dikembangkan berbentuk aplikasi yang termuat dalam perangkat keras berupa smartphone yang tentunya bersistem operasi android.

\section{Hasil Rancangan Materi}

Materi yang akan disajikan di dalam aplikasi dijabarkan menjadi 7 menu yaitu:

Menu materi pertama menyajikan bentuk dasar gerak tari yang dijabarkan menjadi tahap 1 (sikap badan dan kaki), tahap 2 (sikap tangan, kepala, dan mata), dan tahap 3 (sikap pokok dalam tari Cendrawasih). Pada tahap 1 ini jenis sikap badan yang disajikan adalah cengked, sedangkan sikap kaki terdiri dari tapak sirang pada, eed, miles dan nyeregseg. Sikap tangan pada tahap kedua meliputi agem kanan I dalam tari Cendrawasih, agem kiri I dalam tari Cendrawasih, agem kanan II, agem kiri II, dan ukel.
Gerakan kepala terdiri dari ulu wangsul, ngileg, kipek, dan nyegut, sedangkan gerak mata terdiri dari gerakan nelik, seledet kanan, seledet kiri dan ngelier. Tahap 3 menyajikan macam-macam sikap pokok dalam tari Cendrawasih yaitu nyigcig dan ngentrag, agem kanan 1, agem kiri I, agem kanan II, agem kiri II, ngegol, gerakan mekilit, gerak ngehkeh kanan, gerak ngehkeh kiri, ngeberang kampid, nyakupang kampid, ngebet, mesaki, ngenyorin, makeber/ ngindang, makecos, gerak masiksikan I, gerak masiksikan II, gerak masiksikan III, gerak mincang-incangan.

Menu materi kedua adalah menu yang menyajikan ragam gerak tari Cendrawasih bagian pepeson, pengawak, pengecet, dan pekaad. Pembabakan ini bertujuan agar siswa lebih mudah memahami gerakan yang ada.

Menu materi selanjutnya yaitu gerak tari keseluruhan. Setelah siswa mempelajari bentuk gerak dasar hingga gerak perbabak, siswa dapat mempelajari tari secara menyeluruh dengan iringan yang sudah disediakan dalam menu ini.

Menu keempat adalah komposisi tari Cendrawasih. Menu ini menampilkan bentuk-bentuk pola lantai yang dapat digunakan dalam menarikan tari Cendrawasih, seperti diagonal, horizontal, dan vertikal.

Menu kelima yaitu menu yang menyajikan gambaran bentuk kostum tari Cendrawasih secara keseluruhan. Bagian ini menyajikan langkah-langkah menggunakan kostum yang benar dalam tari Cendrawasih. Adapun bentuk kostum tersebut terdiri dari hangkin, rok renda, sayap/ kampid, ampok-ampok, tutup dada, gelang kana, badong lenter, gelungan, bunga merah, bunga putih, dan subeng. Menu keenam adalah kuis. Kuis yang disajikan berupa soal obyektif sebanyak 10 soal. Soal-soal yang dikeluarkan berada diseputaran materi yang disediakan dalam video. Adapun kisi-kisi soal, sebagai berikut.

Tabel 1. Kisi-kisi Soal Pilihan Ganda Pada Menu Kuis

\begin{tabular}{|c|c|c|c|c|}
\hline \multirow{3}{*}{ No } & \multirow{3}{*}{ Indikator } & \multirow{3}{*}{$\begin{array}{l}\text { Tujuan } \\
\text { Pembelajaran }\end{array}$} & Bentuk & \multirow{3}{*}{$\begin{array}{l}\text { Jumlah } \\
\text { soal }\end{array}$} \\
\hline & & & Soal & \\
\hline & & & PG & \\
\hline
\end{tabular}

\begin{tabular}{|c|c|c|c|c|}
\hline 1 & $\begin{array}{l}\text { Definisi tari } \\
\text { Cendrawasih }\end{array}$ & $\begin{array}{l}\text { Siswa dapat men- } \\
\text { jelaskan definisi } \\
\text { tari Cendrawasih }\end{array}$ & $\sqrt{ }$ & 7 \\
\hline 2 & $\begin{array}{l}\text { Ragam ger- } \\
\text { ak dalam tari } \\
\text { Cendrawasih }\end{array}$ & $\begin{array}{l}\text { Siswa dapat } \\
\text { menyebutkan } \\
\text { ragam gerak tari } \\
\text { Cendrawasih }\end{array}$ & $\sqrt{ }$ & 2 \\
\hline
\end{tabular}




\begin{tabular}{llll}
\hline Kostm tari & $\begin{array}{l}\text { Siswa dapat } \\
\text { menyebutkan }\end{array}$ & & \\
nama-nama & $\sqrt{ }$ & 1 \\
& & & \\
& Cendram dalam tari \\
& Cendrawasih & & \\
\hline Jumlah soal & & 10 \\
\hline
\end{tabular}

Menu terakhir berisi tentang kami yaitu identitas aplikasi yang dikembangkan.

\section{Hasil Rancangan Media}

Hasil rancangan media yang dibuat nantinya akan direalisasikan agar menjadi produk yang utuh. Beberapa hasil rancangan aplikasi ini dapat dilihat sebagai berikut.

Rancangan Tampilan Utama

Menu utama terdiri dari menu "masuk" dan "petunjuk" dapat dilihat pada gambar 1

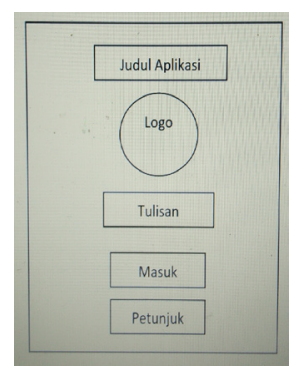

Gambar 1. Rancangan tampilan utama Rancangan Slide Opening

Slide opening berisi salam pembuka, deskripsi tari disertai tampilan slide show foto tari Cendrawasih.

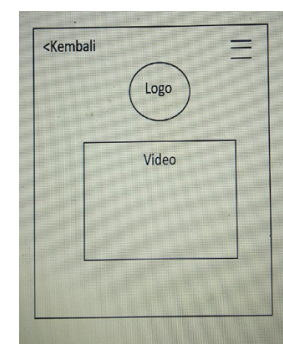

Gambar 2. Rancangan Slide Opening

Rancangan Tampilan Menu Pembelajaran

Tampilan menu yang disajikan dalam aplikasi terdiri dari bentuk dasar gerak, ragam gerak, gerak tari keseluruhan, komposisi tari, pemakaian kostum, kuis dan tentang kami.

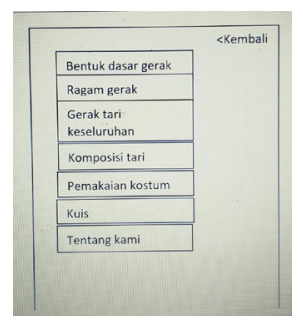

Gambar 3. Rancangan Menu Pembelajaran Rancangan Bentuk Dasar Gerak Tahap 1
Jika memilih menu bentuk dasar gerak tahap 1, terdiri dari menu kembali, logo dan tampilan video gerak badan dan kaki.

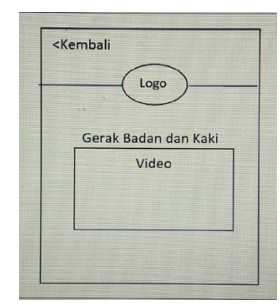

Gambar 4. Rancangan Tampilan Tahap 1

Rancangan Bentuk Dasar Gerak Tahap 2

Menu bentuk dasar gerak tahap 2, terdiri dari menu kembali, logo, dan tayangan video gerak tangan, kepala, dan mata

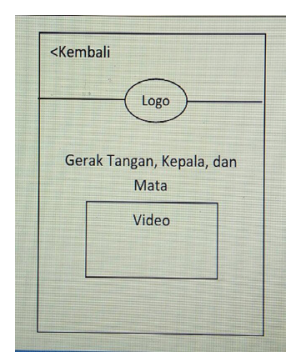

Gambar 5. Rancangan Tampilan Tahap 2

Rancangan Ragam Gerak Tari

Menu ragam gerak tari yang dijabarkan menjadi bagian I (pepeson), II (pengawak), III (pengecet), IV (pekaad). Desain keseluruhan tampilan ini nantinya akan muncul sama pada setiap ragam gerak tari pada peran jantan ataupun peran betina dari tari Cendrawasih.

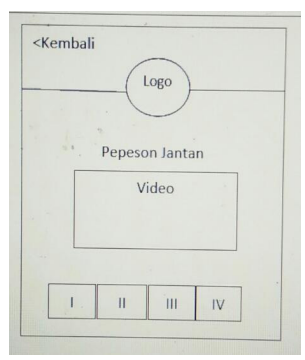

Gambar 6. Rancangan Tampilan Ragam Gerak Rancangan Tampilan Kuis

Tampilan menu kuis menyediakan kolom identitas nama sebelum memulai kuis

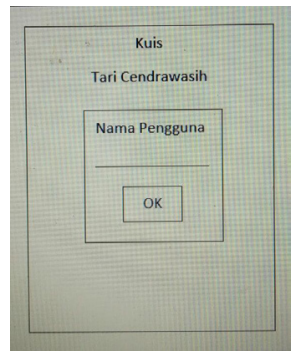

Gambar 7. Rancangan Tampilan Kuis 


\section{Tahap Pengembangan (Develop)}

Pada tahap pengembangan rancangan media video berbasis android direalisasikan menjadi sebuah produk yang nyata. Berikut adalah hasil realisasi dari rancangan sebelumnya.

\section{Implementasi Tampilan Utama}

Pada implementasinya judul aplikasi yang dimaksud berisikan "Aplikasi Pembelajaran Tari Cendrawasih", logo menggambarkan seorang penari, dan tulisan "Ayo Belajar Seni Tari Melalui Ponsel Android Anda Bersama Melestarikan Budaya Bali” Menu masuk dengan latar biru sedangkan menu petunjuk berwarna putih

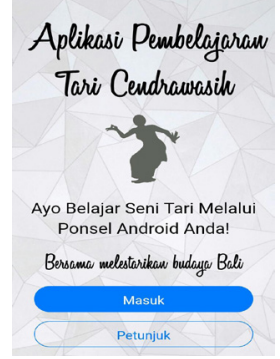

Gambar 8. Implementasi Tampilan Utama Implementasi Slide Opening

Secara umum warna latar yang digunakan adalah abu-abu

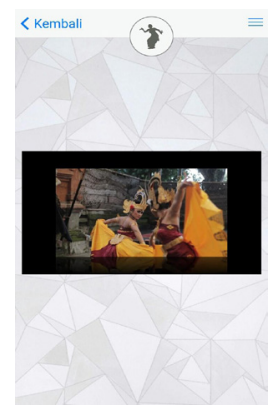

Gambar 9. Implementasi Slide Opening Implementasi Tampilan Menu Pembelajaran Pada implementasinya, menu-menu diberi warna hijau toska dengan latar secara umum menggunakan warna abuabu.

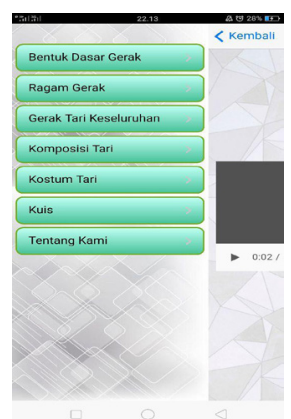

Gambar 10. Implementasi Menu Pembelajaran

Implementasi Dasar Gerak Tahap 1

Secara umum latar yang digunakan berwarna abu-abu dengan tulisan berwarna hitam dan biru. Seluruh tampilan dapat ditampilkan dalam format landscape.

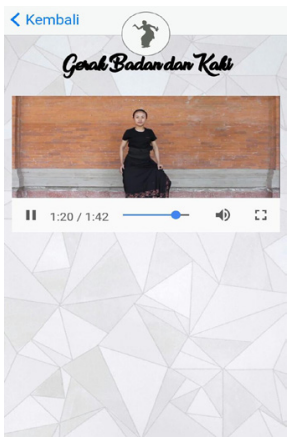

Gambar 11. Implementasi Tampilan Tahap 1 Implementasi Dasar Gerak Tahap 2

Pada implementasi tahap 2 ini yang berbeda adalah judul tulisan yang berisi tentang gerak tangan, kepala, dan mata. Pengguna atau user dapat mem-pause atau mengulang kembali tarian sesuai kebutuhan. Tampilan dapat dilihat pada gambar berikut.

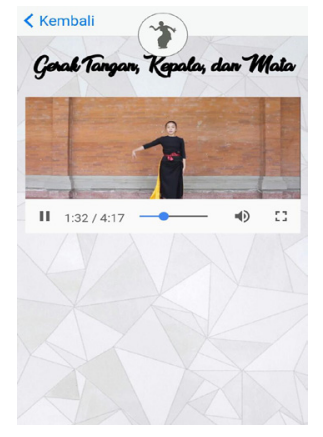

Gambar 12. Implementasi Tampilan Tahap 2

Implementasi Tampilan Ragam Gerak Tari

Pada implementasinya nama-nama pembabakan tari akan muncul sesuai dengan pilihan yang diinginkan. Menu "I" untuk bagian pepeson, menu "II" bagian pengawak, menu "III" bagian pengecet, menu "IV" bagian pekaad.

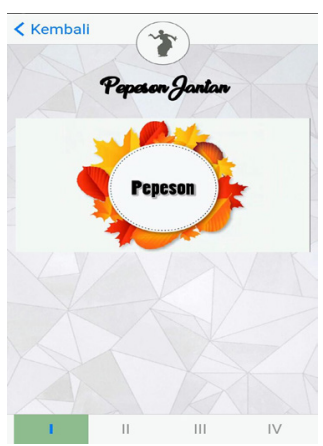

Gambar 13. Implementasi Ragam Gerak Tari 
Implementasi Tampilan Kuis

Pada tampilan kuis, latar yang digunakan saat munculnya kolom pengisian data adalah bayangan dari soal yang akan dikerjakan seperti gambar dibawah ini.

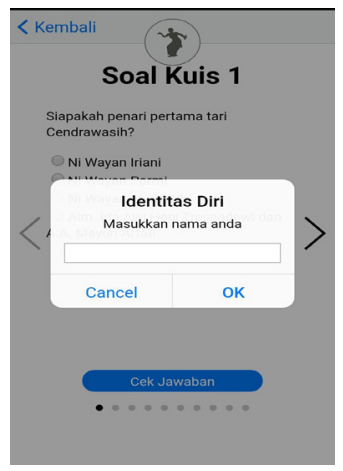

Gambar 14. Implementasi Tampilan kuis

\section{SIMPULAN}

Berdasarkan penelitian dan pengembangan aplikasi pembelajaran tari Bali berbasis android dengan mengambil materi tari Cendrawasih yang telah dilakukan maka diperoleh kesimpulan aplikasi pembelajaran tari Bali berbasis android merupakan aplikasi yang menampilkan bentuk gerak tari Cendrawasih yang disusun secara sistematis dan terstruktur dengan menggunakan android studio untuk menjalankan media ke dalam smartphone bersistem operasi android. Proses dan perancangan aplikasi telah berhasil dilakukan dengan menggunakan acuan model pengembangan Four-D oleh Thiagarajan yang saat ini telah terlaksana pada tiga tahap yaitu define, design, dan develop. Aplikasi telah berhasil diimplementasikan sesuai dengan rancangan yang telah dibuat sebelumnya dengan adanya perpaduan warna antara hijau toska, abu-abu, hitam, biru, kuning, dan orange.

\section{UCAPAN TERIMA KASIH}

Pada kesempatan ini penulis mengucapkan terima kasih kepada Dr. N.L.N Swasthi Widjaya Bandem selaku pencipta tari Cendrawasih yang telah memberikan informasi, serta tim pengembangan yang telah membantu dalam setiap proses, beserta semua pihak yang terlibat secara langsung ataupun tidak langsung yang tidak dapat disebutkan satu persatu pada tulisan ini diucapkan terima kasih. Semoga karya ilmiah ini dapat berguna bagi masyarakat.

\section{DAFTAR RUJUKAN}

Agnestria, Rizki. (2016). Pengembangan Buku Pengayaan Berbasis Aktivitas Membaca Berpikir Terbimbing Untuk Meningkatkan Hasil Belajar Membaca Intensif Siswa Kelas IV SD (Tesis yang tidak dipublikasikan). Universitas Negeri Surabaya.

Al Musawi, Ali S. (2010). The Instructional and Learning Technologies Department (ILT) in the College of Education, Sultan Qaboos University. Educational Media and Technology Yearbook, 35. doi: 10.1007/978-1-4419-1516$0 \_7$

Arikunto, Suharsimi. 2006. Prosedur Penelitian Suatu Pendekatan Praktek. Jakarta: Rineka Cipta.

Arini, Anak Agung Ayu Kusuma. 2011. Tari Kekebyaran Ciptaan I Nyoman Kaler. Denpasar: Pelawa Sari.

Arsyad, Azhar. 2010. Media Pembelajaran. Jakarta: PT RajaGrafindo Persada.

Bandem, I Made., \& I Wayan Dibia. 1983. Pengembangan Tari Bali. Denpasar: ASTI.

Bandem, I Made. 2004. Kaja Dan Kelod Tarian Bali Dalam Transisi. Jogjakarta: Institut Seni Indonesia Jogjakarta.

Creswell, John W. 2015. Penelitian Kualitatif \& Desain Riset Memilih Diantara Lima Pendekatan. Yogyakarta: Pustaka Pelajar.

Dahar, Ratna Willis. 1988. Teori-Teori Belajar. Jakarta: Departemen Pendidikan dan Kebudayaan.

2006. Teori-Teori Belajar dan Pembelajaran. Bandung: Erlangga.

Daryanto. 2013. Media Pembelajaran Peranannya Sangat Penting Dalam Mencapai Tujuan Pembelajaran. Yogyakarta: Gava Media.

Dantes, N. 2014. Landasan Pendidikan Tinjauan Dari Dimensi Makropedagogis. Singaraja: Program Pascasarjana Universitas Pendidikan Ganesha.

Dibia, I Wayan. 1999. Selayang Pandang Seni Pertunjukan Bali. Bandung: Masyarakat Seni Pertunjukan Indonesia dengan arti.line

2007. Etnokoreologi Nusantara (Batasan kajian, sistematika, dan aplikasi keilmuannya). Surakarta: ISI Press.

2013. Puspasari Seni Tari Bali. Badung:

UPT ISI Badung. 
Djayus, Nyoman. 1980. Teori Tari Bali. Denpasar: CV Sumber Mas Bali

Djiwandono, Sri Esti Wuryani. 2002. Psikologi Pendidikan. Jakarta: PT Gramedia Widiasarana Indonesia.

Dreyfus, Stuart E. (2004). The Five Stage Model of Adult Skill Acquisition. Bulletin of Science, Technology \& Society. Sage publications. Doi:10.1177/0270467604264992

Hergenhahn, B.R., dan Olson, M.Hg. 2008. Theories Of Learning (Teori Belajar). Jakarta: Kencana.

H Safaat, Nazaruddin. 2015. Android Pemrograman Aplikasi Mobile Smartphone Dan Tablet Pc Berbasis Android. Bandung: Informatika

Jensen. Rita A dkk. 1994. Using Audio-Visual Technology As a Tool For Reflection In Teacher Education. Annual Meeting of the association of teacher education.

Joesoef, Soelaman. 1992. Konsep Dasar Pendidikan Non Formal. Jakarta: Bumi Aksara.

Kertiasih, Ni Ketut. "Pengembangan Media Pembelajaran Berbasis Multimedia Gerakan Dasar Tari Bali”. Jurnal Pendidikan Teknologi dan Kejuruan Fakultas Teknik dan Kejuruan UNDIKSHA. 6 (1). 37-50.

Krisnadi, Elang \& Pribadi. Modul Pendamping Pengembangan Bahan Ajar Non Cetak. Jakarta: Direktorat Ketenagaan, Direktorat Jenderal Pendidikan Tinggi, Kementerian Pendidikan Nasional.

Muktar dan Iskandar. 2010. Desain Pembelajaran Berbasis TIK. Jambi: Referensi

Munadi, Yudhi. 2013. Media Pembelajaran Sebuah Pendekatan Baru. Jakarta: Referensi

Musfiqon. 2012. Pengembangan Media dan Sumber Pembelajaran. Jakarta: Prestasi Pustakaraya

Ngalimun, Haris Fadillah, Alpha Ariani. 2013. Perkembangan Dan Pengembangan Kreativitas. Yogyakarta: Aswaja Pressindo

Poerdawarminta. 1999. Psikologi Komunikasi. Jakarta: UT

Prawiradilaga, Dewi Salma. 2007. Prinsip Disain Pembelajaran: Instructional Design Principles. Jakarta: Prenada Media Group

Purwanto, M. Ngalim. 2002. Psikologi Pendidikan. Bandung: Remaja Rosda Karya
Rahayuningtyas, Wida, dkk. (2011). Metode Pembelajaran Pencantrikan Terbimbing Dengan Pemanfaatan Audio Visual. Jurnal Harmonia. 11(1), 27-31.

Riduwan. 2005. Skala Pengukuran Variabel-Variabel Penelitian. Bandung: Alfabeta.

Rusdewanti, Panca Putri, dan Abdul Gafur. (2014). Pengembangan Media Pembelajaran Interaktif Seni Musik Untuk Siswa SMP. Jurnal Inovasi Teknologi Pendidikan 1(2), 153-164.

Ruseffendi. 2006. Pengantar Kepada Membantu Guru Mengembangkan Kompetensinya Dalam Pengajaran Matematika Untuk Meningkatkan CBSA. Bandung : Tarsito.

Sadiman, Arif S., dkk. 2005. Media Pendidikan: Pengertian, Pengembangan dan Pemanfaatannya. Jakarta: PT RajaGrafindo Persada.

Sardiman. 1992. Interaksi dan Motivasi Belajar Mengajar. Pedoman Bagi Guru dan Calon Guru.

Sarwono, Sarlito W. 2013. Psikologi Remaja. Jakarta: Rajawali Pers.

Setiaji, Rony Siswo. (2016). Pengembangan Media Pembelajaran Multimedia Interaktif Kolase, Mosaik dan Montase Untuk Calon Guru Sekolah Dasar (Tesis yang tidak dipublikasikan). Universitas Negeri Surabaya, Surabaya.

Shattuck, Gary. (2010). Understanding School Leaders'Role in Teachers' Adoption of Technology Integration Classroom Practices. Educational Media and Technology Yearbook, 35. doi: 10.1007/978-1-4419-1516-0_2

Slameto. 2003. Belajar dan Faktor-faktor yang Mempengaruhinya. Jakarta:Rineka Cipta.

Slavin, R.E. 2000. Educational Psychology: Theory and Practice. Boston: Allyn \& Bacon.

Sobur, Alex. 2013. Psikologi Umum Dalam Lintasan Sejarah. Bandung: CV Pustaka Setia.

Sudjana, Nana \& Ahmad Rivai. 2010. Media Pengajaran. Bandung: Sinar Baru Algensindo.

Sugiyono. 2016. Cara Mudah Menyusun Skripsi, Tesis dan Disertasi. Bandung: Alfabeta.

Sugiyono. 2017. Statistika Untuk Penelitian. Bandung: Alfabeta.

Sukiman. 2012. Pengembangan Media Pembelajaran. Yogyakarta: Pedagogia. 
Suparman, Atwi. 1997. Desain Instruksional. Jakarta: PAU-PPAI Direktorat Jendral Pendidikan Tinggi Departemen Pendidikan dan Kebudayaan.

Suprihatiningrum, Jamil. 2013. Strategi Pembelajaran Teori \& Aplikasi. Yogyakarta: AR-RUZZ MEDIA.

Surya Pratama Wardhana, I Putu, I Gede Mahendra Darmawiguna, dkk. (2015). Pengembangan Aplikasi Instrumen Gamelan Gong Kebyar Berbasis Android. JANAPATI. 4 (2), 58-66.

Sustiawati, Ni Luh. (2008). Pengembangan Manajemen Pelatihan Seni Tari Multikultural Berpendekatan Silang Gaya Tari Bagi Guru Seni Tari Sekolah Menengah Pertama Negeri di Kota Denpasar (Disertasi yang tidak dipublikasikan). Universitas Negeri Malang, Malang.

Suwidnya, I Gede. (2015). Pengembangan Model Pembelajaran Menabuh Gamelan Gender Wayang Bali Dengan Teknik Belajar Siti Playing (Tesis yang tidak dipublikasikan). Universitas Negeri Surabaya, Surabaya.

Tan, Seng-Chee, Beaumie Kim, \& Jennifer Yeo. (2010). Learning with Technology: Learner Voice and Agency. Educational Media and Technology Yearbook, 35. doi: 10.1007/978-1-4419-1516-0_8

Trianto. 2007. Model-Model Pembelajaran Inovatif Berorientasi Konstruktivistik: Konsep, Landasan Teoritis-Praktis dan Implementasinya. Jakarta: Prestasi Pustaka.

. Model Pembelajaran Terpadu Dalam Teori dan Praktek. Jakarta: Prestasi Pustaka.

Uno, Hamzah B. 2015. Teori Motivasi \& Pengukurannya Analisis di Bidang Pendidikan. Jakarta: Bumi Aksara.

Warsita, Bambang. 2008. Teknologi Pembelajaran Landasan \& Aplikasinya. Jakarta: Rineka Cipta.

Yamin, Martinis. 2013. Strategi \& Metode Dalam Model Pembelajaran. Jakarta:Referensi (GP Press Group)

Yudhaningtyas, Sesaria Prima. (2017). Pengembangan Video Pembelajaran Tari Pada Program Beasiswa Seni Budaya Indonesia (BSBI) di Jawa Timur (Tesis yang tidak dipublikasikan). Universitas Negeri Surabaya, Surabaya. 